\title{
Hierarchical to Gender Egalitarianism: Women Empowerment and Emancipation through Micro Finance in Rural Nepal
}

\author{
Dr. Prakash Upadhyay
}

\begin{abstract}
The major objective of this paper is to identify the efficacy of Micro Finance in women empowerment and to explore the ramifications of awareness and socioeconomic alterations owing to Micro Finance program. Both quantitative and qualitative data from primary and secondary sources were used in the study. The instruments of primary data collection were questionnaire, observation, interview and focus group discussion. Pedestal on gender theories examining status and power differences related to gender empowerment, role of caste, ethnicity, culture and, to some extent, class status in shaping individuals and problems, this study deduced that gender empowerment is a transformation of gender relations from hierarchal to egalitarian plan rather than just women's power position and this has been doable through Micro Finance which has proved to be the financial selfsustainable paradigm. Microfinance program has supported to women's income generating and livelihood activities and helped in poverty reduction owing to which rural women's life style and way of living is altering. Gender empowerment through Micro Finance incorporates emancipation and empowerment of women without creating a misgiving of emasculation of men. Emancipation of women is procuring economic, social and political rights and equality meant for fostering a balance in gender relations as against the one-sided women empowerment approach.
\end{abstract}

Keywords: Offshoot, modish, gender equality, bucolic, patriarchy ridden, hooliganism

\section{Introduction}

Gender and feminism are the sombre notions to be discussed owing to the rise of gender sensitivity since 1960's. It has taken hold of human imagination like never before. For all practical purposes, the concern of gender equity has graduated to the level of policy objectives (Sharma, 2000). In Nepal gender equity and women empowerment are critically conversed topics. Womenfolk comprises more than $50 \%$ of total population, however their backwardness is a result of many factors viz. patriarchal norms and values which is offshoot of illiteracy and lack of property ownership. Women empowerment is a modish concept to improve relationship and reduce gender inequalities in Nepali society because empowerment gives power to dominated people and it gives suggestion to reduce power to dominant people. Many scholars discussed empowerment as human potential especially for women empowerment. Caroline Moser (1993), at first, discussed it as redistribution of power. But as a concept, 'empowerment' is widely used, but seldom defined. The often-uncritical use of the term "empowerment" in development thinking and practice disguises a problematic concept. There is a room for greater clarity about the concept and its application. Confusion arises with the concept of empowerment because the root concept 'power' is itself disputed. Power has been the subject of debate in social science. 
Nevertheless, empowerment is one course of action to create equality and justice in society. It creates equality and makes aware to people and gives power to stay free from injustice in society. Batliwala (1993) notes that empowerment is the prices of gaining control over the self over ideology and the resources which determine power. It is a construct shared by many disciplines and arenas: community development, psychology, education, economics, and studies of social movements and organizations, among others. How empowerment is understood varies among these perspectives. In empowerment literature, the meaning of the term empowerment is often assumed rather than explained or defined. Rapport (1984) argue that it is easy to define empowerment by its absence, but difficult to define in action, as it takes on different forms in different people and contexts. Even defining the concept is subject to debate. Conversing on empowerment, Rawland (1997) argues that in order to understand the process of empowerment, there is a need to be aware that power can take many different forms- Power over, Power to Generative or Productive power, Power with a sense of the whole being, Power from within. Zimmerman (1984) has stated that asserting a single definition of empowerment may make attempts to achieve it formulaic or prescription-like, contradicting the very concept of empowerment. A common understanding of empowerment is necessary, however, to allow us to know empowerment is vital when we see it in people with whom we are working, and for program evaluation (Bailey, 1992).

Micro Finance is one of the most effectual weapons to empower and augment the life standard of people. It is an appropriate program for women empowerment and poverty alleviation. The terms Micro refers very small and finance means the art and science of managing money. It is the management of small amount of money, providing small loan to poor families so that they can involve in productive activities and nurture their small business. In the past, Micro-finance was focused on providing a very standardized credit product but with passage of time, focus has been laid on value amounts targeted at low income clients. It includes loans, savings, insurance, transfer services and other services (Sharma, 2005). Micro Finance includes credit, savings and insurance and poor households have an access to the capital that helps to create or expand microenterprises.

Micro Finance encourages women to do something and gives loan without collateral to women and only believes in group members. It provides training to women to empower in her work and phenomenon. It has been one of the few effective tools for poverty reduction over the past years through sound Micro Finance institution and systems in various parts of Nepal. Poor people can deposit money and accumulate funds for future investments or emergencies as well as access to credit for productive purposes leading to higher income. Additionally, Micro Finance produces an impact in other areas including good governance, participation in political processes, women empowerment, social inclusion and conflict transformation.

\subsection{Conceptual Framework}

Drawing profoundly on gender theories, the conceptual frame of the study underpins on handy program of Micro Finance to empower women and to uplift their life style and reduce poverty. Micro Finance provides training and skill to empower women, support to bring equality in life of women in the society, promotes saving habit and investment capacity as well. The conceptual frame depicts the cogs of women empowerment through Micro Finance in decision making power, awareness, opportunity, training, employment, access etc. 
Figure 1: Conceptual framework

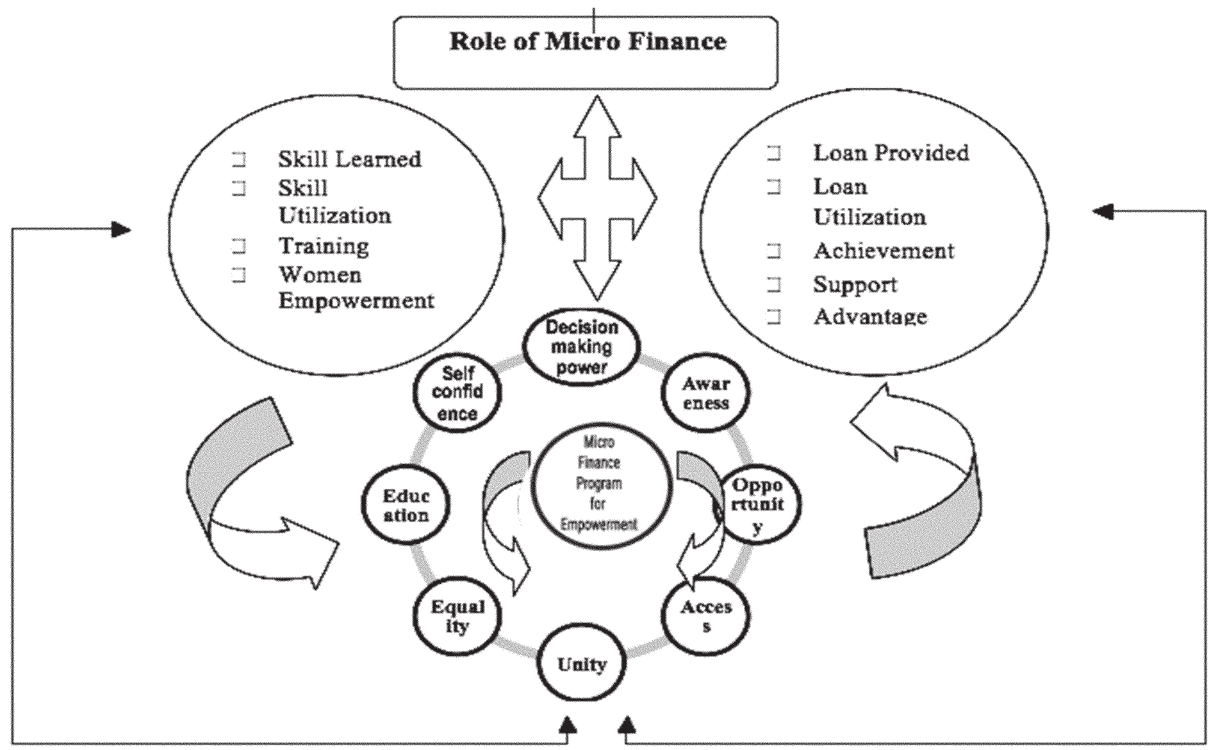

\section{Problems and Objectives}

At grass-roots level Micro Finance creates positive impact to reduce extreme poverty and it is a financial self-sustainability paradigm too. The financial services saving and credit enables clients to increase their household's incomes, build assets and reduce their susceptibility to rise. Without women's economic and social enhancement in the rural context, development of nation is unthinkable hence women empowerment through Micro Finance is exceptionally vital and it is a major apparatus to fight against poverty, inequalities and patriarchal yoke. It has got the potentiality to emancipate and augment women's status in the bucolic context of Nepal. Given this vitality, the key objective of this paper is to identify the efficacy of Micro Finance in women empowerment and to explore the ramifications of awareness and socio-economic alterations (poverty and gender inequalities reduction) owing to Micro Finance program.

\section{Data and Methods}

This study is pedestal on both primary and secondary sources of data. Data were generated through primary field studies and secondary literature review. Both qualitative and quantitative data were used. The study site is located in Biruwa Archale Village Development Committee (VDC) of Syangja district of western Nepal. In this VDC, 216 women are involved with Muktinath Bikas Bank Limited (MBBL) Micro Finance program. 110 women respondents were selected based on purposive stratified sampling. The instruments of primary data collection were Questionnaire, Observation, Interview and Focus Group Discussion. The data collection task was accomplished during November 15 to December 9, 2015.

\subsection{Profile of Study Site and Respondents}

Study site Biruwa Archale VDC is located between east and south of Syangja district of western Nepal. This VDC covers 10.88 sq. Km area. The total population of the VDC follows: 
Table 1: Total population of Biruwa Archale VDC

\begin{tabular}{|c|c|c|c|c|}
\hline Ward No. & Household & Total Male & Total Female & Total Population \\
\hline 1 & 61 & 170 & 147 & 317 \\
\hline 2 & 85 & 276 & 267 & 543 \\
\hline 3 & 54 & 208 & 204 & 412 \\
\hline 4 & 60 & 235 & 208 & 443 \\
\hline 5 & 78 & 244 & 223 & 467 \\
\hline 6 & 118 & 381 & 358 & 739 \\
\hline 7 & 79 & 260 & 257 & 517 \\
\hline 8 & 51 & 205 & 202 & 407 \\
\hline 9 & 36 & 102 & 92 & 194 \\
\hline Total & 622 & 2081 & 1958 & 4039 \\
\hline
\end{tabular}

Source: VDC profile, Biruwa Archale, 2015

Altogether there are 622 households in Biruwa Archale with a total male population of 2081 (51.52\%) and female population of 1958 (48.47\%). The total population of the VDC is 4039.

\section{Disusion and Analysis}

\subsection{Occupational Distribution of Biruwa Archale VDC}

Table 2 depicts that majority population is dependent on agriculture. 78.10 percent people depend on agriculture for their livelihood.

Table 2: Occupational distribution of Biruwa Archale VDC

\begin{tabular}{|l|c|c|}
\hline \multicolumn{1}{|c|}{ Occupation } & Total Number & Percentage \\
\hline Agriculture & 1281 & 78.10 \\
\hline Trade/Business & 53 & 3.23 \\
\hline Job & 254 & 15.48 \\
\hline Labour & 52 & 3.17 \\
\hline Total & 1640 & $99.98 \%$ \\
\hline
\end{tabular}

Source: VDC profile, Biruwa Archale, 2015

15.48 percent population depend on job. 3.23 percent people are relying on trade and business.

Educational Status of Age group 6-60 above by Caste in Biruwa Archale VDC

Table 3 portray 6-60 above age group's educational status. Analogous to national trend, male literacy rate is higher than female in this village. 
Table 3: Educational status of age group 6-60 above by caste

\begin{tabular}{|l|c|c|c|c|}
\hline \multirow{2}{*}{ Caste } & \multicolumn{2}{|c|}{ Literacy Rate } & \multicolumn{2}{c|}{ Illiteracy Rate } \\
\cline { 2 - 5 } & Male & Female & Male & Female \\
\hline Brahmin & 51 & 48 & 10 & 17 \\
\hline Chhetri & 326 & 367 & 21 & 81 \\
\hline Magar & 192 & 158 & 12 & 37 \\
\hline Gurung & 603 & 482 & 99 & 189 \\
\hline Dalit & 133 & 92 & 25 & 41 \\
\hline Other & 3 & 4 & 3 & 0 \\
\hline Total & 1308 & 1151 & 170 & 365 \\
\hline
\end{tabular}

Source: VDC profile, Biruwa Archale, 2015

Female illiteracy rate is higher than male. This depicts women's diffident social status.

Age Level of Sampled Women Respondents

Table 4 portray the sampled women respondents who are from different age groups and are involved with Micro Finance program.

Table 4: Age level of the respondents

\begin{tabular}{|c|c|c|}
\hline Age Group & No. of Respondents & Percentage \\
\hline $20-30$ & 42 & 38.18 \\
\hline $31-40$ & 40 & 36.36 \\
\hline $41-50$ & 21 & 19.09 \\
\hline $51+$ & 7 & 6.36 \\
\hline Total & 110 & $99.99 \%$ \\
\hline
\end{tabular}

Source: Field Survey, 2015

20-30 age group (38.18\%) women respondents' involvement is high in Micro Finance program. 31-40 age groups respondents are 36.36 in percent. 41-50 and 50+ age groups women respondents are in minority. It clarifies that 20-40 age groups respondents are more vigorous in Micro Finance program.

\subsection{Caste/Ethnic Distribution of Respondents}

Caste is a grouping that is based primarily on heredity or birth. People from a caste generally share a common culture. This term is used most often with the system of caste that exists in Hindu societies of Nepal. According to this division of classes, the whole society is divided in four broad castes named Brahmin, Kshatriya, Vaishya, and Shudra. Contrary, ethnic group or Janajati is socially defined category of people who identify with each other based on common ancestral, social, cultural or national experience. Ethnic group's identity is defined by a common ancestry, origin myth, shared heritage, history, homeland, customs, dialect and occasionally ideology. Ethnic groups of Nepal are mainly from mongoloid stock of population. The table below clarifies caste /ethnic distribution of women respondents.

52 
Table 5: Caste/ethnicity

\begin{tabular}{|l|c|c|}
\hline \multicolumn{1}{|c|}{ Caste } & No. of Respondents & Percentage \\
\hline Brahmin/Chhetri & 34 & 30.90 \\
\hline Ethnic Groups (Janajati) & 58 & 52.72 \\
\hline Dalit & 17 & 15.45 \\
\hline Muslim & 1 & 0.90 \\
\hline Total & 110 & $99.99 \%$ \\
\hline
\end{tabular}

Source: Field Survey, 2015

\subsection{Educational Backdrop of Women Respondents}

Education converts a biological human into a social human. However, education requires instruction of some sort from an individual or composed literature. The most common forms of education result from years of schooling that incorporates studies of a variety of subjects. Table 6 clarifies the educational background of respondents. Majority women's education level is up to primary level.

Table 6: Educational backdrop

\begin{tabular}{|l|c|c|}
\hline \multicolumn{1}{|c|}{ Educational Level } & No. of Respondents & Percentage \\
\hline Illiterate & 8 & 7.27 \\
\hline Only literate & 22 & 20.00 \\
\hline Primary & 40 & 36.36 \\
\hline SLC and Above & 11 & 10.00 \\
\hline Secondary & 29 & 26.36 \\
\hline Total & 110 & $99.99 \%$ \\
\hline
\end{tabular}

Source: Field Survey, 2015

36.36 percent respondents have passed primary level, 26.36 percent respondents are educated up to secondary levels, 20 percent respondents are only literate and 10 percent respondents are educated up to SLC and above level.

\subsection{Occupational Distribution of Respondents}

Occupations focus on positions that require skills that may be used in a number of different work settings, allowing the individual with that skill set to move with relative ease from one occupational sector to another as the need arises. Occupation enables economic enhancement and brings positive changes in behaviour, supports economic condition and helps in maintaining the household. Occupational distribution of respondents follows in table 7 . For the majority (80.90\%), agriculture is the major occupation. 
Table 7: Occupational distribution

\begin{tabular}{|l|c|c|}
\hline Occupation & No. of Respondents & Percentage \\
\hline Agriculture & 89 & 80.90 \\
\hline Business & 19 & 17.27 \\
\hline Job & 2 & 1.81 \\
\hline Total & 110 & $99.99 \%$ \\
\hline
\end{tabular}

Source: Field Survey, 2015

17.27 percent respondents' occupation is business and only 1.81 percent respondents has job. As only few women are highly educated hence only few women are involved with jobs.

\subsection{Marital Status of Respondents}

Family starts with a married life. Marital status is necessary for the comprehension of developmental status of the society and nation. Married women respondents are in majority with a percentage of 86.36. Married women are mainly involved with Micro Finance program because of their heavy economic burden; need of more money to manage household expenses and also because of expressive roles within family. Widow respondents are 12.72 in percentage.

Table 8: Marital status

\begin{tabular}{|l|c|c|}
\hline \multicolumn{1}{|c|}{ Marital Status } & No. of Respondents & Percentage \\
\hline Married & 95 & 86.36 \\
\hline Unmarried & 1 & 0.90 \\
\hline Single (widow) & 14 & 12.72 \\
\hline Total & 110 & $99.99 \%$ \\
\hline
\end{tabular}

Source: Field Survey, 2015

\section{Findings}

Feminist theories according to Poorman (2003) examine role expectations and status and power differences related to gender while empowerment theory looks more specifically at the role of race/ethnicity/culture and, to some extent, class status in shaping individuals and problems. Contemporary feminist theorists seek gender difference, inequality, oppression, suppression of women through the landscape of institutions and socialization (Ritzer, 2000). For them gender division of labour, the doctrine of private public sphere in which women are restricted to work as a house worker, mother, care-giver results in women's less privileged position, subordination, and domination. The labour division confines women in private expressive world (within the chores of household) and men in public world that creates different situation and experiences for them. In Biruwa Archale VDC, the same tendency had existed before women joined in Micro Finance program. Previously womenfolk were confined in private world within the chores of household.

Muktinath Bikas Bank started the Micro Finance program in all branches of Kaski, Syangja and Tanahun districts since 2008. This Bank has branch in Biruwa Archale VDC too which 
focuses on women empowerment in economic sector through Micro Finance program. It makes group of women and it gives loan without collateral to women and believe on group members. Situation and place wise, it gives different types of training to women to do productive activities. Micro Finance program of this bank has focused to women in productive areas like agriculture, livestock and small business and tried to empower women in various forms owing to which women are abandoning their traditional household tasks and entering the public world of challenge-with new forms of power experiencing.

\subsection{Respondents Experience after Joining Micro Finance Program}

Women have a myriad of expressions, behaviours, language, emotions, etc. that characterize and convey moment-to-moment experiences with Micro fiancé program. Table 9 illustrate that majority respondents (98.18) are happy and contended after joining Micro Finance program.

Table 9: Women's experience after joining micro finance program

\begin{tabular}{|l|c|c|}
\hline \multicolumn{1}{|c|}{ Experience } & No. of Respondents & Percentage \\
\hline Happy & 108 & 98.18 \\
\hline Unhappy & 2 & 1.81 \\
\hline Total & 110 & $99.99 \%$ \\
\hline
\end{tabular}

Source: Field Survey, 2015

Micro Finance program is incredibly useful to respondents especially those who are active and optimistic to do something. Unhappy are those who are old and economically inactive. Hence they are not interested and want to quit the group.

\subsection{Changes after Joining Micro Finance Program}

To make something different, women can cause something to change, or they can bring change upon themselves. Table 10 corroborate that there has been increase in self-confidence of women after they join Micro Finance-which is a kind of empowerment.

Table 10: Changes after joining micro finance program

\begin{tabular}{|l|c|c|}
\hline \multicolumn{1}{|c|}{ Change } & No. of Respondents & Percentage \\
\hline Social and Economic changes & 32 & 29.09 \\
\hline Increase of Self confidence & 54 & 49.09 \\
\hline Realized Importance of Time & 5 & 5.54 \\
\hline Social, Economic \& Self Confidence & 15 & 13.63 \\
\hline Positive thinking & 4 & 3.36 \\
\hline Total & 110 & 99.98 \\
\hline
\end{tabular}

Source: Field Survey, 2015

49.09 percent respondents increased their self confidence, 29.09 percent respondents noticed social and economic improvement. 13.63 percent respondents changed socially, 
economically and developed self-confidence, and 5.54 percent respondents realized the importance of time.

\subsection{Skills Learned from Micro Finance Program}

Few of the respondents received training from Micro Finance Program of Muktinath bank. The trainings received and skills learned by women are as follows:

Table 11: Skills learned

\begin{tabular}{|l|c|c|}
\hline \multicolumn{1}{|c|}{ Training } & No. of Respondents & Percentage \\
\hline Cutting and sewing clothes & 2 & 28.57 \\
\hline Medical First Aid & 1 & 14.28 \\
\hline Curry Production & 4 & 57.14 \\
\hline Total & 7 & $99.99 \%$ \\
\hline
\end{tabular}

Source: Field Survey, 2015

Only 7 respondents received training. Respondents learning curry production are in majority. They also received trainings in cutting and sewing. These trainings and skills learned are proving quite supportive for women empowerment and enhancing women eminence.

\subsection{Impacts of Participation in Micro Finance Program}

The majority of the respondents $(55.45 \%)$ feel easy and are enthusiastic to participate in development process. Table 12 shows the impact of participation in Micro Finance program.

Table 12: Impacts of participation

\begin{tabular}{|l|c|c|}
\hline \multicolumn{1}{|c|}{ Impact } & No. of Respondents & Percentage \\
\hline Poverty reduction and skill development & 3 & 2.72 \\
\hline $\begin{array}{l}\text { Easy and help to participate in self and social devel- } \\
\text { opment process }\end{array}$ & 61 & 55.45 \\
\hline Empower to influence development process & 33 & 30.00 \\
\hline Access of help to investment and poverty reduction & 13 & 11.81 \\
\hline Total & 110 & $99.98 \%$ \\
\hline
\end{tabular}

Source: Field Survey, 2015

30 percent respondents are empowered to influence development process, 11.81 percent respondents are having access of help to investment and poverty reduction after participating in Micro Finance program. An impact can be a forceful effect. The impact of Micro Finance program has been both advantageous as well as disadvantageous for women empowerment. 


\subsection{Loan Provided to Women}

The Micro Finance Program is providing loans to its members in different forms. Table 13 shed light on loan provided to women.

Table 13: Loan provided to women

\begin{tabular}{|l|c|c|}
\hline \multicolumn{1}{|c|}{ Loan } & No. of Respondents & Percentage \\
\hline Yes & 105 & 95.45 \\
\hline No & 5 & 4.54 \\
\hline Total & 110 & $99.99 \%$ \\
\hline
\end{tabular}

Source: Field Survey, 2015

Loan was provided to majority respondents (95.45\%). Very few have not taken any loan. It clarifies that majority respondents are active and they want to do something to reduce poverty and economic inequalities hence they have taken loans.

\subsection{Utilization of Loan}

The loan utilization is high in livestock investment. Out of 105 loan takers, two respondents do not made utilization of loan in any sort of investment but 103 respondents made good utilization of loan. 74.75 percent respondents made utilization of loan in livestock.

Table 14: Loan utilization

\begin{tabular}{|l|c|c|}
\hline \multicolumn{1}{|c|}{ Sector } & No. of Respondents & Percentage \\
\hline Livestock & 77 & 74.75 \\
\hline Trade & 23 & 22.33 \\
\hline Agriculture & 3 & 2.91 \\
\hline Total & 103 & $99.99 \%$ \\
\hline
\end{tabular}

Source: Field Survey, 2015

22.33 percent respondents made utilization of loan in trade and 2.91 percent respondents made utilization of loan in agricultural sector. Livestock is the main occupation with a good investment. Figure 2 illustrates that 54.54 percent respondents made utilization of loan in goat keeping, 23.37 percent in buffalo keeping, and 12.98 percent in pig rearing. This investment on animal husbandry is enhancing the economic eminence not only of women but of their entire family due to which women have been empowered additionally.

\subsection{Women Empowerment as Emancipation}

Kabeer (1989) interprets empowerment as a redial transformation of power relations between women and men so that women have greater power over their own lives and men have less power over women's lives. Carr (2003) notes that empowerment must be anchored within women's own experiences. Feminist empowerment approach believes that financial institution as Micro Finance brings constructive social, economic and political change in women. It brings self-confidence, gender equality, awareness of social 
problems and issues. Self-confidence is one of the most crucial concepts relating to both women's perception of their capabilities and their actual level of skills and capabilities. Ackerly (1995) notes that when women members play leadership roles in group leaders on centre leaders, they experience increased sense of self confidence and self-worth.

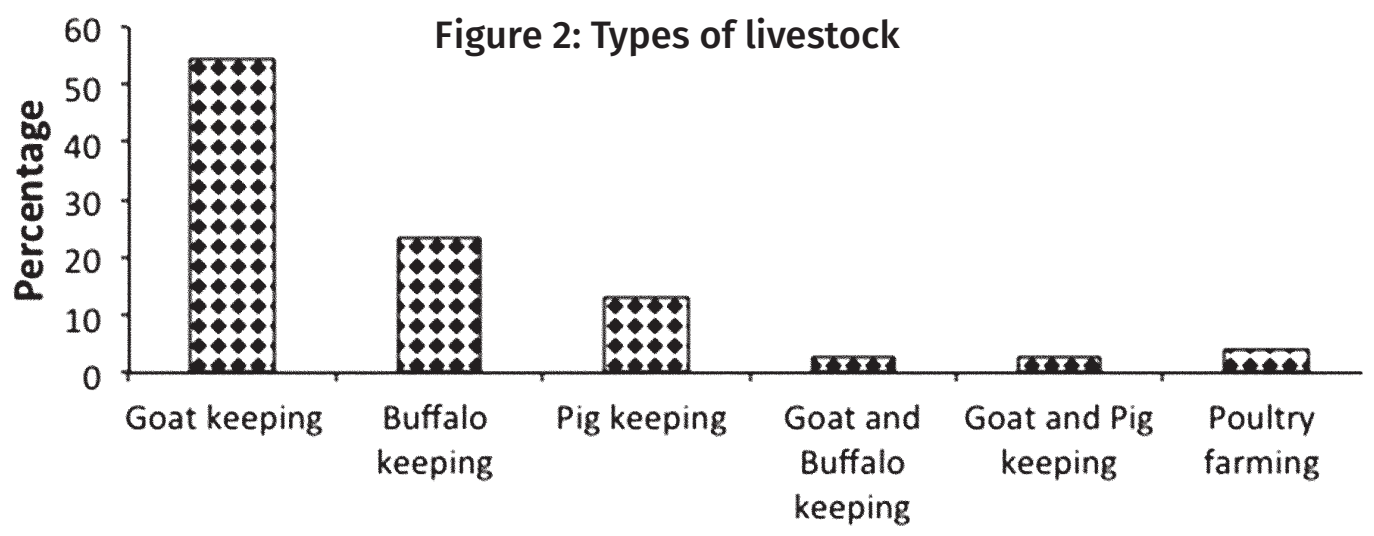

Source: Field Survey, 2015

In this current study on Micro Finance beneficiaries, alteration in self confidence of women has been assessed in terms of the level of their confidence as felt by themselves before and after their participation in the Micro Finance. Rise in self confidence has resulted in various sorts of other positive alterations. The living standard with health, sanitation, empowerment and information has improved in the context of 28.97 percent respondents. 28.03 percent respondents are involved with changes in decision making, education and justice that has created awareness and highlighted the importance of education and attachment to justice. 19.62 percent respondents reported of social and gender relation change that has brought improvement in relation and reduced inequalities in society. 14.01 percent respondent's ownership of property has increased and economic status altered. 9.34 percent respondents do saving and focus on investment that encourage them to do something and utilize the time to increase family income.

Broadly, there has been the reduction in gender inequality and poverty after women's involvement in Micro Finance program. Poverty is about not only having enough money to meet basic needs including food, clothing and shelter it is more, much more in social, cultural terms than just not having enough money. Among the women, poverty is reducing due to Micro Finance loan utilization. Gender inequality springs when women have less power than men do or vice versa. The social construct results in women not having equal rights, opportunities, or privileges to men; however this condition has been changed due to women empowerment through Micro Finance-which is a kind of emancipation from social obstructions.

Empowerment and consequent rise in self confidence is proving to be a kind of emancipation for women, a process to obtain economic and social rights, political rights or equality entailing equal status in society, equality in property, and other private characteristics. Some of the other dimensions of empowerment in different forms swathe up areas as improving relations with husbands, decision making, social relations etc. 
Table 15: Positive Alteration among respondents

\begin{tabular}{|l|c|c|}
\hline \multicolumn{1}{|c|}{ Change } & No. of Respondents & Percentage \\
\hline Familial Saving and focus on Investment & 10 & 9.34 \\
\hline $\begin{array}{l}\text { Ownership of property \& development of family } \\
\text { and social economy }\end{array}$ & 15 & 14.01 \\
\hline Social and gender relation improvement & 21 & 19.62 \\
\hline $\begin{array}{l}\text { Health sanitation empowerment \& information } \\
\text { access }\end{array}$ & 31 & 28.97 \\
\hline Decision making, Education and Justice & 30 & 28.03 \\
\hline Total & 107 & 99.97 \\
\hline
\end{tabular}

Source: Field Survey, 2015

\subsection{Relationship with Husband}

Table 17 illustrates women's changing relationship with their husbands that have been altered after their (women) involvement with Micro Finance.

Table 16: Relationship with husband

\begin{tabular}{|l|c|c|}
\hline \multicolumn{1}{|c|}{ Relation } & No. of Respondents & Percentage \\
\hline Moribund (Stagnant) & 35 & 31.81 \\
\hline Deterioration in relation & 2 & 1.81 \\
\hline Improvement & 73 & 66.36 \\
\hline Total & 110 & $99.98 \%$ \\
\hline
\end{tabular}

Source: Field survey, 2015

The table reveals improving relationship of women with their husbands and the positive role played by Micro Finance to empower women and the family. 66.36 percent respondents' relationship has improved with their spouses. 31.81 percent respondent's relation is in status -quo or stagnant stipulation and 1.81 percent respondents' relationship deteriorated with their spouses after their involvement with Micro Finance which is due to distrust on each other.

\subsection{Decision Making of Women in Familial Activities}

According to Karl (1995) the term empowerment captures the sense of gaining control and participation in decision-making which is a term used to describe the process by which families make choices, determine judgments, and come to conclusions that guide behaviours. Table 17 illustrates decision making role of women in detail after their involvement with Micro Finance.

79.09 percent respondents are having decision making with mutual understanding/ advice of each other in families activities which is a positive sign that has been possible 
due to women's involvement with Micro Finance. 17.27 respondents used to take self decisions in families activities. Especially they are single women and some other married respondents also. 3.63 respondents decision making is only by husband. Some respondents are dependent on husband and subjugated by husband till now and there has been no change in women's status.

Table 17: Decision making role of women in families activities

\begin{tabular}{|l|c|c|}
\hline Decision making & No. of Respondents & Percentage \\
\hline Self (Women) & 19 & 17.27 \\
\hline Husband & 4 & 3.63 \\
\hline Mutual advice of each other & 87 & 79.09 \\
\hline Total & 110 & $99.99 \%$ \\
\hline
\end{tabular}

Source: Field Survey, 2015

\subsection{Social Relation Built after Involvement in Micro Finance Program}

Participation in any venture empowers people to voice their opinions, concerns and encourages them to speak for themselves. This often means consulting people on particular issues, inviting them to events, or asking them to be members of formal groups and networks that have a focus on involving people. The table below illustrate that 94.54 percent respondents' relation amplified with friends, relatives and society after their involvement in Micro Finance program.

Table 18: Relation built after involvement in micro finance program

\begin{tabular}{|l|c|c|}
\hline \multicolumn{1}{|c|}{ Relation } & No. of Respondents & Percentage \\
\hline Increase & 104 & 94.54 \\
\hline Decrease & 3 & 3.72 \\
\hline Stagnant & 3 & 2.72 \\
\hline Total & 110 & $99.98 \%$ \\
\hline
\end{tabular}

Source: Field Survey, 2015

However, 3.72 percentage respondents relation decreased and 2.72 percent respondent's relation is moribund after involvement in Micro Finance program. Women with increased relation with friends' are in majority after their involvement in Micro Finance program owing to which their social relation has been budding up and women are becoming more and more powerful and emancipated. This emancipation of women is procuring economic and social rights, political rights and equality.

\section{Conclusions and Recommendations}

This study deduced that gender empowerment should not be mistaken for empowerment of man vis-a-vis woman or the vice versa. Empowerment, in fact, is a kind of emancipation, a transformation of gender relations from hierarchal to egalitarian plan and this has been possible through Micro Finance that has been working for gender relations in a complimentary framework rather than a conflictual framework. Gender empowerment has 
proved to be a broad category which includes empowerment of women without creating a misgiving of emasculation of men. It stands for promotion, a balance in gender relations as against the one-sided women empowerment approach. Additionally, empowerment is not just a question of rearrangement of power both economic and political; it is also an issue of change of values. Men need gender sensitization as much as women do. In fact men need it even more, for they still are in a position of domination on account of the perpetuation of patriarchy. Nepali proverb two wheels of the same cart supports this notion. Male and female are the equal construction of nature despite biological dissimilarities; however, patriarchy ridden gender inequalities have created disparities. Many programs have been introduced by government and other agencies to uplift women's economic and sociocultural status focused on the context of rural women. One of them, Micro Finance is the major and important program which focuses to uplift the economic and social condition of rural poor women. It is vital for poverty reduction, to decrease social disparities and to empower women in many respects. It supports sustainable development also. It is the financial self sustainable paradigm too.

Supportive through various trainings, vegetable farming, livestock rearing and women awareness program, Micro Finance program has supported to women's income generating and livelihood activities. Their life style and way of living is changing through this program. This program has opened the door of future career of women, empowering women to generate income and sustain socio-economic independence and enhancing women's interest in participating in development program. Micro Finance program has increased social awareness of women that has helped women in development process. Women are empowering with increasing relationship between family and society. Women's friend relationship is escalating and they are taking about their problems and discussing solutions with friend. They are participating more and more in decision making process in family and society which has brought improvement in family and society, reshaped family relationship and has enhanced the decision making power of women in the home and society.

Women should be encouraged more in production and saving. Micro Finance Program should also focus on that area where the economic and social consequences aren't great. Women ought to be encouraged to reduce and challenge local male dominated nuisances like gambling, alcoholism, hooliganism etc. Micro Finance loan should be provided in subsidized rate to the economically vulnerable women at low interests. Awareness building education program should be launched to eliminate gender and caste discriminations and programs should be implemented effectively for the real needy.

\section{BIBLIOGRAPHY}

Ackerly, B. A. (1995). Testing the tools of development: Credit programs loan involvement and women's empowerment. IDS Bulletin, 26(3), 55-68.

Bailey, D. (1992). Using participatory research in community consortia development and evaluation: Lessons from the beginning of a story. American Sociologist, 23(4), 71-82.

Batliwala, S. (1993). Empowerment of women in south asia, concepts and practices.New Delhi: FAO.

Carr, E. S. (2003). Rethinking empowerment theory using a feminist lens: The importance 
processes. Affilia, 18(8), 8-20.

Kabeer, N. (2003). Reversed realities: Gender hierarchies in development thought. London: Verso.

Karl, M. (1995). Empowerment and women. London: Zed Books.

Moser, C. (1993). Gender planning and development: Theory, practice and training. London: Routledge.

Poorman, P. B. (2003). Micro skills and theoretical foundations for professional helpers. Boston: Allyn and Bacon.

Rapport, J. (1984). Studies in empowerment: Introduction to the issue. Prevention in Human Services, 3, 1-7.

Ritzer, G. (1983). Sociological theories. McGraw-Hill Higher Education.

Rowland, J. (1997). Questioning Empowerment. Oxford: Oxfam.

Sharma P. R. (2005). Millennium development goals and international year of M.F. 2005 in Nepal. The Journal of Nepalese Business Studies, 2(1). 87-94.

Zimmerman, M. A. (1984). Taking aim on empowerment research: On the distinction between individual and psychological conceptions. American Journal of Community Psychology, 18(1), 169-177. 